\title{
LAZARUS SLAVIN IN THE CONTEXT OF DEVELOPMENT OF INSTITUTIONAL ARCHAEOLOGY DURING PREWAR PERIOD IN UKRAINIAN SSR (1938-1941)
}

\author{
Daria CHERKASKA \\ Centre of Archaeology Department of Humanities and Performing Arts \\ Staffordshire University, L214, Flaxman Building Stoke-on-Trent ST4 2DE, \\ e-mail: dcherkasskaya@gmail.com
}

\begin{abstract}
The development of archaeological science in Ukraine during the Soviet period is closely associated with the activities of Lazarus Slavin (1906-1971) - Member of the Academy of Sciences, specialist at ancient Greek studies, candidate of histotical sciences, professor, founder and head of the department of archeology and museology at Taras Shevchenko Kyiv State University Taras Shevchenko. The professional activity of Lazarus Slavin coincided with a difficult period for science when research objectives were not those of objectivity and scientific merit, but concepts and dogmas defined by the state as articles of faith. This is why this dissertation is looking at this activity not only from the standpoint of evolution of scientific thought but also in terms of political influence, not only upon Lazarus Slavin, but the humanitarian science as a whole. It is quite probable that during his entire scientific career Lazarus Slavin has remained a Soviet researcher, whose methodological principal was that of a formation. However, his professional and personal qualities, work experience and the love for archaeology have enabled him to reinstate Kyiv archaeological institute as a powerful centre of Soviet science after the repressions of 1930s and the devastation of the World War II.
\end{abstract}

Key words: Lasarus Slavin, Soviet Archaeology, Institute of Archaeology National Academy of Science of Ukraine, 1930's, institutional archaeology.

The process of development of archaeological science in Ukraine in prewar period was rather complex and controversial. In order to analyze the role of Lazarus Slavin in organizing archaeological institutions it is necessary to review the overall situation in scientific community during that period. 1930's saw the finalization of institutional formation of archaeology as a research science, which ideologically was subject to Stalin's interpretation of Marxism. This process coincided with the period of political repressions in Soviet society and with introduction of Communist Party bureaucrats as those in charge of science instead of professionals. It also became the demarcation point in transition from "old bourgeois" science to "new Marxist-Leninist" one.

It would be unfair to say that this period has been properly covered in modern historiography. This is mostly due because that studying of this time in history of this scholar is complicated by the fact that practically all the documents from Institute of Archaeology of Academy of Science of Ukrainian SSR dating from 1938 onwards were destroyed during evacuation of the institution in June-July of 1941. However, Slavin's function in management roles in Institute of Archaeology is mentioned in several types of publications:

- Works dedicated to jubilees of Ukrainian SSR Academy of Sciences (AN UkSSR) and its subdivisions (Institute of History, Institute of Archaeology). Their common feature is expositive style of describing facts and strict adherence to Marxist-Leninist teachings with propagandist intentions [50 лет Институту археологи, 1984].

- There is another group of publications which study scientific and management activities of Lazarus Slavin in leadership roles at AN UkSSR. His work as a director of Institute of Archaeology AN UkSSR is described in articles in scientific journals, commemorating his legacy [Корпусова, 2007, 1996; Станіцина, 2007]. 
He works of scholars representing Ukrainian diaspora should be mentioned separately. These works, dedicated to history of archaeology and All-Ukrainian Academy of Sciences (VUAN), contain generalizations of factual material. They should also be treated more as memoirs than scientific research based on archives [Полонська-Василенко, 1993, 1962; Курінний, 1994; Миллер, 1954; Міллер, 1962; Пастернак, 1961].

It is also worth highlighting the works describing the activity of Lazarus Slavin in academic institutions (Institute of History, Institute of Archaeology) that were published after Ukrainian independence [Інститут історії України..., 2011; Інститут археології..., 2015]. However, unlike the similar papers published during Soviet period, modern Ukrainian historiography views Soviet historical science in context of socio-political processes that were taking place in the country and criticizes ideological focus of scientific research of that period.

Midway thru 1930's the function of All-Ukrainian Archaeological Committee (VUAK) was essentially reorganized. Responsibility for archaeological research was transferred to Institute of history of material culture (IIMK) (at first it was just a sector, then a department (SIMK)), which became a model of Soviet representation of studies of ancient history. The official reasons for reorganizing VUAK were insufficient level of use of Marxist-Leninist ideology by specialists in their work; lack of research archaeologists from "sister republics" participating in expeditions in Ukraine [Шовкопляс, 1969, XVII].

The process of transformation of VUAK's work into Institute of history of material culture was interpreted by different researchers in different ways. Nataliya Polons'ka-Vasylenko mentions that VUAK was shut down in 1933, but later on the same page she wrote that "SIMK has attracted six viable institutions of All-Ukrainian Academy of Sciences that already had significant scientific tenure, measurable results, a solid team of staffers and a distinct scientific persona" [Полонська-Василенко, 1993, c. 24]. Petro Kurinnyi wrote that "The section was formed instead of a significant number of UAN institutions in order to do away with separation of social sciences and to redirect them to study human culture on Marxist-Leninist basis" [Курінний, 1994, с. 117]. However, the author mentions that in order to achieve that goal it was necessary to "free up from work" (lay off - DC) several scientists that were part of old organization. It is particularly interesting, especially in context of studying the science management activity of Lazarus Slavin, to reference his own view of the events: "In order to restructure the archaeological work in Ukraine, the Academy of Science of Ukrainian SSR has started, in 1934, to organize the Institute of history of material sciences on basis of VUAK and other archaeological institutions that were part of Academy of Science" [Славін, 1947, с. 69]. Ivan Shovkoplias interprets this process as one of several consequences of reorganization of Academy of Sciences. But the researcher also mentions liquidation of VUAK, which served as a basis for new institution [Шовкопляс, 1969, XVIII]. So, the process of reorganizing the functions of VUAK into IIMK is described somewhat similarly by multiple researchers, but the emotional impression of described facts varies quite significantly. Examples of different viewpoints by multiple researchers become crucial to understanding the reasons why Lazarus Slavin, a scholar from Leningrad, later on became the head of Ukrainian Soviet archaeology.

From institutional standpoint the reorganization of Soviet Ukrainian archaeology fit quite well into general restructuring of institutions studying history of Ukrainian SSR. Second half of 1930's till beginning of 1940's is the period of completion of "Sovetization" of institutes of AN UkSSR [Iсторик i Влада, 2016, с. 62]. One of the manifestations of this process was the decision to create Institute of history in 1936 (23.07.1936 memorandum from Central Committee of Communistic party (bolshevikov) of Ukraine; 27.07.1936 memorandum from Executive Committee of AN UkSSR comprised of several departments (first of all, departments of history of T. G. Shevchenko Kyiv State University) and commissions of AN UkSSR and Institute of Ukrainian History at VUAMLIN ${ }^{1}$ As far

${ }^{1}$ All-Ukrainian Association of Marxist-Leninist Institutes was created out of Ukrainian Institute of Marxism and Leninism, founded in 1922 in Kharkov, which, similar to other institutes of "red professors", was preparing Communist party workers for teaching in higher institutions. The Association was comprised of six research institutions (history, 
as Ukrainian Soviet archeological science was concerned, this was, on one hand, a period of change in methods of conducting archaeological studies, but on the other hand, a period of introduction of Marxist concepts into studying of the past.

In order to more fully comprehend the activities of Lazarus Slavin in management roles one needs to carefully analyze the conditions leading to his transfer. And for that it would be necessary to trace the processes that were taking place in institutional archaeology of UkSSR in second half of 1930s, both in USSR and UkSSR.

After the cleansing that was conducted amongst the employees of VUAK there were virtual no archeologists left in Ukraine and the archaeological expeditions have almost ceased. Sector of History of Material Culture (1933-1934), Institute of History of Material Culture (1934-1938) and Institute of Archaeology were "all formal organizations without any real purpose" [Миллер, 1954, с. 112]. The list of active members of VUAK as of 1933 states that there were 28 such members in Kyiv [HA IA НАНУ, ф. 60, спр. 462, арк. 2]. The document, however, has handwritten notes which state that 7 members were deported, 4 were excluded and 4 died. The list of those that were members of VUAK and lived outside of Kyiv also contains similar notes [HA IA НАНУ, ф. 60, спр. 462, арк. 3]. The list is comprised of 12 domestic VUAK members and 3 foreign ones. Four of those were deported, 2 were excluded and one died. According to the list of SIMK employees, there were 13 workers in 1933. Only four of them were actual members of VUAK (Mykola Makarenko, Valeria Kozlovs'ka, Ippolit Morgilevsky, Mikhailo Rudynskii) [HA IA НАНУ, ф. 59, спр. 471, арк. 8].

History institutions of Soviet Union were always under close control of those in charge, and these institutions were one of the first ones to be mauled by cleansings and repressions. It was during that period, which Vladimir Gening called structural reorganization of central archaeological institutions, when archaeology was introduced to the goals and methods of archaeological explorations according to Marxist-Leninist ideology [Генинг, 1982, с. 50-56]. The amount of archeological expeditions decreases significantly during that period. And it is that difficult period when the activity of "party-appointed" directors: Fedor Kozubovski, Nikolay Yachmeniov, and Lazarus Slavin, took place.

The professional training of Fedor Kozubovski was quite substantial: he studied in Smolensk Teachers' Institute and in 1929-1933 was a fellow of Odessa Archeological Museum [Мезенцева, 1997, c. 18-19]. It was during his tenure that the scientific activity of Institute of History of Material Culture was redefined within guidelines of class-proletariat ideology and was directed to study consistency of historical development coupled with material production.

Natalia Polons'ka-Vasylenko characterized the activity of an institution as a task of mastering the work of classics of Marxism [Полонська-Василенко, 1993, с. 24]. Mikhail Miller was even more radical and called SIMK "a semi-fictional institution" that deserved to be called that due to absence of professional archaeologists [Міллер, 1962, с. 79]. In fact, both researchers, despite their radical views, were to some extent correct. It was due to the fact that the first half of 1930's became the period of formation of Soviet Marxist archaeology. This is the time when several discussions were held on topic of search for new methods of conducting archaeological explorations, and more importantly, their purpose. Lazarus Slavin had this view of IIMK's work: “However, from the very beginning IIMK took a wrong direction. The institute did not have a clearly defined profile of its work, was trying to apply its skills in archaeology, ethnography, history of machinery, and even such topics that had no connection with its profile (like, studying the progress of electrification of agriculture and so on), and that, coupled with lack of personnel, led to a loss of engagements in main archeological field'[Славін, 1943, c. 69]. In fact, reorganization of archaeological institutions in Kyiv was part of much bigger process of reorganizing the entire Soviet archaeology. For instance, an article named "On issues of

philosophy and natural science, economics, law and Soviet development, agricultural, and human resources) and two departments (nationality issues and study of literature). Later on there were three branches created: Kyev, Odesa and Dnipropetrovsk, as well as propaganda and distance learning section. Fourteen scientific communities were part of this association as well. 
methodological changes to archaeology" [HA IA HAHУ, ф. 60, спр. 686 а, арк. 82], which expresses an opinion of an unidentified author on presentation by Artem Artsikhovsky and Vladimir Nikolsky at First Conference of Marxist Historians, highlights that because of a need to study archaeological cultures in conjunction with each other and not as separate ones archaeology should be considering not "ethnographic" but "sociological" aspects. Fedor Kozubovski, in compliance with directives of Joseph Stalin at XVII Soviet Communistic party (bolshevikov) Congress, pointed out that one of the main goals of history of material culture should be the study of incipience of cities in conjunction with development of division of labour in society: "To establish the incipience of cities and their role in communal and economic life" [HA IA HAHУ, ф. 60, спр. 638, арк. 8]. Besides methodologicaltheoretical research of the topic and goals of history of material culture this theme was also quite relevant in the context of rapidly developing policy of country's industrialization.

The personality of Nikolai Yachmeniov has not been extensively studied by modern historiography. On $15^{\text {th }}$ of October 1935 he was appointed director of Institute of History of Material Culture. The important thing to note here is the term "appointed". Soviet leadership was of an opinion that a successful manager can lead any organization without any specific professional background. The main requirement was adherence to Marxist-Leninist ideology. Nikolai Yachmeniov was exactly the type of "professional Communist" with no ties to science. He was sent from Moscow to Kyiv in order to transform Ukrainian Soviet archaeology to become a proper Marxist-Leninist science (in fact he was to complete extermination of "enemies of the people" and "disturbers" within the organization). The draft version of an article written by V. Telichko and N. Yachmeniov states the essence of professional activity of Institute of Archaeology when it was led by Nikolai Yachmeniov: "Soviet science is based on Marxist-Leninist methodology, which makes it a powerful weapon in a battle for Communism" [HA IA HAHУ, ф. 60, спр. 637, арк. 1]. And no one but a "professional Communist" had to lead this battle. Nikolay Yachmeniov was a graduate of Leningrad Communist Institute, then studied at Institute of Red Professors (completed two years) [Колесникова, Михайлова, Черновол, Науменко, 2008, с. 107] and then was appointed the director of institute until $2^{\text {nd }}$ of September 1940 [Станіцина, 2007, c. 25], at which time he was transferred to an administrative role in a trade school in Lviv [Інститут археологіï..., 2015, с. 295]. During Yachmeniov's tenure there were many "old-school specialists" that had positions at Institute of Archaeology in Kyiv (Prof. Oleksandr Ogloblin, Victor Petrov). This is the review that was given to Victor Petrov by Nikolay Yachmeniov: "I also have this employee Petrov, I need to think about him. He has a doctorate in literature. Based on our conversations I'm getting an impression that I'm not going to get much use out of him and I'd have to have him fired." [Колесникова, Михайлова, Черновол, Науменко, 2008, с. 107] This type of review shows that Nikolai Yachmeniov wasn't particularly skilled in human resources, because Victor Petrov had experience in researching a wide variety of archaeological monuments: Tripolian culture, Scythian and Early-Slav settlements. As of 1936 there were 19 science workers in Institute of Archaeology. Besides archaeology they were working on ethnography, history of machines and even chemical laboratory.

The Institute was severely short on professional resources, and there were also shortages of material ones. "Institutes of Social Division, after their renovation in 1936, ended up in very uncomfortable locations. Archaeology, Literature, Languages, History - all of them were located on the top floor of former First Boys Gymnasium, on Shevchenko Boulevard, in the mezzanine, where there student living quarters used to be" [Полонська-Василенко, 1993, с. 88]. The space was completely unfit for work, it had low ceilings, but was very big, and badly lit.

In 1936 the works completion report stated that employees of IIMK AN UkSSR concentrated their research on prehistoric monuments, ancient colonies of Northern Black Sea Region (Olbia), history of manufacturing and machines [HA IA HAHУ ф. 60, спр. 614, арк. 4]. Topics of research were very much following then-current tendencies in history science and were fitting into scientific discourse of Soviet history science of mid 1930's. So the following year the topics were harshly criticized. For example, President of AN UkSSR Oleksandr Bogomolets pointed out that besides research of Olbia by Institute of Archaeology the rest of research amounts to collection of "some" 
materials (he meant archaeological artifacts - DC) [Полонська-Василенко, 1993, с. 96]. The Institute's leadership, represented by N. Yachmeniov and science secretary V. Telichko, had to report to institutes in Moscow and Leningrad (probably as per directive from Communistic party for sending science personnel from places such as State Academy of History of Material Culture (GAIMK) to Kyiv) [HA IA HAHУ ф. 60, спр. 614, арк. 5]. According to documents, in 1935 V. Telichko visited Leningrad to familiarize himself with structure and activities of GAIMK [HA IA НАНУ ф. 60, спр. 623, арк. 45]. In 1936 Lazarus Slavin on GAIMK’s petition had several long-term trips in Ukraine SSR to work in Kyiv, Nikolaev and Odessa. It is worth mentioning that the process of transition from VUAK to IIMK was rather lengthy and multi-staged. Consequently, inviting a specialist from GAIMK was a logical step of reorganization of institutional archaeology in USSR and specifically in UkSSR.

In order to restore scientific activities of the Institute Lazarus Slavin was invited to Kyiv in 1938 as an assistant scientific director of Archaeology Institute. His transfer to Kyiv, first and foremost, was tied to the fact that there were no professional archaeologists left in Kyiv as a result of repressions and exterminations: "Archaeology in Ukraine was restored, but without any Ukrainian archaeologists." [Полонська-Василенко, 1993, с. 112]. At first this transfer was supposed to last only a year [Научный архив ..., ф. 35, оп. 5, арк. 282] $]^{2}$, but, due to some circumstances, the scholar ended up working in Institute of Archaeology of AN UkSSR until his death on $30^{\text {th }}$ of November 1971. An invitation of a scientist from Leningrad for a leadership role at Archaeology Institute fit into an important goal that was consistent with ideological foundations of Marxist-Stalinist principles, which resulted in combining scientific and methodological principles in main archaeological centers dating back from Russian Empire: Moscow, Leningrad (St. Petersburg) and Kyiv (centers in other cities of Soviet Union were not mentioned, but it was certainly an nationwide campaign - DC). The foundation of this unification was the abandonment of "bourgeois matter-science", which meant renunciation from studying a concrete object, separated from larger context of a monument or a group of monuments, with a goal of looking for concrete objects and moving towards studying the entire monument for further reconstruction of society during that era. This approach fit very well into Marxist paradigm of science which was used back then [Trigger, 1989, p. 251]. It was important to obtain the entire complex of materials from studied site. This approach was very much in line with methodological principles, founded by Boris Farmakovski, Lazarus Slavin's mentor.

It goes without saying that in totalitarian societies such as Soviet Union management positions in science institutions were given to scientists loyal to the state. And clearly, Lazarus Slavin, as a representative of "new Soviet scientist" generation fit that definition completely. However, his professional qualifications, his experience in archaeological expeditions, and his personal qualities, which were crucially important for a manager, allowed him to not just be a nominal leader of IA AN UkSSR, but to develop science and to resurrect archaeological research for entire republic.

Since December 1939 Lazarus Slavin started teaching archaeology for department of ancient history at Taras Shevchenko Kyiv State University. Also, in 1939 the scholar was elected membercorrespondent of AN UkSSR [Архів Президії...]. In 1940, after Nikolai Yachmeniov got transferred to Lviv, Lazarus was appointed director of Institute of Archaeology by Executive Committee of AN UkSSR. That same year he was accepted into Communist Party. It is worth pointing out that Lazarus Slavin was sent to UkSSR not to create a brand new organization, but to restore Archaeology Institute after the institution lost the majority of its employees due to series of repressions of 1930's. Besides organizing archaeological research, during that period Archaeology Institute of AN UkSSR led by its director was actively participating in collaborations with other institutes of AN UkSSR, primarily with Institute of History of Ukrainn.

Second half of 1930s witnessed the final stage of institutional formation of history science in RSFSR. The primary task of its representatives was to craft scientific and popular-science literature for researchers, students and general public. First, it was necessary to summarize the research conducted

\footnotetext{
${ }^{2}$ Data courtesy of Liubov Samoilenko.
} 
by Soviet scientists; second, the lack of textbooks and supplemental materials for college students needed to be fulfilled; and lastly, history science had to reflect and support the dogmas and theses that were the foundation of domestic policy of Communistic Party.

In addition, Party membership becomes important: unlike in 1920's management roles are mostly given to either active members or candidates for membership in Communistic party. According to personnel files, the scholar was only elected to become Party member in October 1940 (Party membership №10440133), and he was never a member of VLKSM [Научный архив ..., ф. 35, оп. 5, арк. 282]. This doesn't, however, indicate incompetency or "party preference", but is yet another proof of catastrophic situation with resources after multiple "cleansings" and repressions. According to Sergii Buiskih, expressed in a private conversation, Lazarus Slavin applied for Communistic party membership while he was still in Leningrad. However, according to standard procedure there had to be a waiting period between the time of application until official confirmation (approximately 2 years, but no one can confirm this with any documentation at this time).

Besides his specialized education, Lazarus Slavin had significant practical experience working at State Academy of History of Material Culture in Leningrad, which was the leading center of studying archaeological monuments of Northern Black Sea Region. In 1937 State Academy of History of Material Culture was renamed Institute of History of Material Culture of Academy of Sciences of USSR and lost its autonomous status [Миллер, 1954, с. 105]. That mostly had to do with the fact that the institute in Leningrad was now under supervision of Moscow. It is possible that one of manifestations of this transformation into closer ties was a transfer of Leningrad-based scientist to a management role in Kyiv.

The main goal of archaeology at that time is to reinforce a thesis about "common genesis of Eastern Slavs", which was based on results of excavations that affirmed the initial domicile of these tribes in Eastern Europe [Полонська-Василенко, 1993, с. 112]. This fact is supported by evidence of three major expeditions conducted by Archaeology Institute which were researching "pre-feudal and feudal cities": settlements of Raiki, Kyiv and Vyshgorod (not counting minor studies) [HA IA HAHY ф. 60, спр. 630, арк. 3-4]. Besides that, the expedition for Kyiv antiquities was spearheaded by Michael Karger who came from Moscow. However, unlike Lazarus Slavin, this scientist only came for work visit and was sending a large portion of artifacts obtained during excavations back to Moscow.

Archaeologists were in fact given a task to create scientific foundation of a theory of "three brotherly Slavic nations": Russian, Ukrainian and Belorussian, that had common ancestry, history and culture.

Lazarus Slavin, having personal connections with Leningrad Institute of History of Material Culture, has assisted integration of Ukrainian archaeology into Soviet mainstream. However, he was a scholar, and not just a manager, so as soon as he moved to Kyiv, he was actively engaged in research process. Michael Miller noted that it was Lazarus Slavin that described the beginning of his work in Ukraine as if he would have to create archaeology "on an empty spot" [Миллер, 1954, c. 106]. This meant that besides scientific and organizational tasks Lazarus Slavin had to fill up the Institute's staff. Yet another challenge he faced was the lack of professional training of archaeologists in higher institutions that were specializing in archaeology of monuments in UkSSR.

During the tenure of Lazarus Slavin as director of Institute of Archaeology a number of large scientific conferences were called and conducted, with attendance of up to 100 archeologists, anthropologists and geologists from all over Soviet Union, primarily from Moscow and Leningrad. None of these conferences were attended by chairmen of Leningrad Institute of History of Material Culture and Moscow Institute of History of Material Culture - Mikhail Artamonov and Alexander Udaltsov, respectively [Миллер, 1954, с. 106]. The need for conferences of such magnitude was not doubted by anyone, and they should have been conducted by Leningrad Institute of Material Culture as the main nationwide institution, but, because of absence of necessary conditions there (most likely, because they got reappointed under Moscow - DC), the Institute of Archaeology of AN UkSSR helmed by its acting director Lazarus Slavin took the lead of getting them organized [Славин, 1940, 
c. 200-207; Шовкопляс, 1969, XXIII-XXIV]. Not only was he getting them organized, but he also made sure that they did happen and that they were conducted at high professional and logistical levels.

To summarize, in 1938 Lazarus Slavin was transferred to Kyiv for a short tenure of one year. A scholar that did not have any significant management background was able to realize himself as both an excellent researcher and a great manager. However, one should not discount the fact that his appointment was done for political reasons and that as a leader Lazarus Slavin had to follow "party line" in development of archaeology.

\section{ЛІТЕРАТУРА}

50 лет Институту археологии АН УССР. (1984). - Киев. - 138 с.

Архів Президії НАН України. Ф. Р-251 Відділ наукових кадрів і аспірантури. Особова справа Л. М. Славіна. Справа без вихідних даних.

Генинг В.Ф. (1982). Очерки по истории советской археологии (у истоков формирования марксистських теоретических основ советской археологи. 20-е - первая половина 30-х годов). -Київ. - 228 с.

Інститут археології Національної академії наук України. 1918-2014. (2015). / Гол. ред. П. П. Толочко. - Київ. - 668 с.

Інститут історії України Національної академії наук України. Документи і матеріали. 1936-1991: Книга 1. 1936 - 1947. (2011). / Відп. ред. В. А. Смолій. - Київ. - 630 с.

Історик і Влада. (2016) Колективна монографія / Відп. ред. В. Смолій. - Київ. - 543 с.

Колесникова В. А., Михайлова Н. Р., Черновол I. В., Науменко Н. В. (2008). Історія Наукової бібліотеки Інституту археології НАН України // Археологія. - №. 4. - С. 104-111.

Корпусова В. М. (2007). Лазар Мойсейович Славін - Директор Інституту археології Академії Наук України // Археологія. - №. 1. - С. 31-39.

Корпусова В. Н. (1996). Л. М. Славин - директор Института археологии Украины // Мир Ольвии. К 90-летию проф. Л. М. Славина. - С. 24-31.

Курінний П. П. (1994). Історія археологічного знання про Україну. - Полтава. - 140 с.

Мезенцева Г. Г. (1997). Дослідники археології України. Енциклопедичний словник. - Чернігів. - 206 с.

Миллер М. А. (1954). Археология в СССР. - Мюнхен. - 160 с.

Міллер М. О. (1962). Доля українських археологів під совєтами // Записки Наукового товариства ім. Т. Г. Шевченка: Збірник на пошану українських учених знищених большевицькою Москвою. T. 173. - C. 112-126.

НА ІА НАНУ. Ф. 59 ВУАК - Спр. 686 а. Хроніка археології та мистецтва. - Київ. - Ч. 1.

НА ІА НАНУ. Ф. 59 ВУАК - Спр. 462. Списки членів ВУАК. - 69 арк.

НА ІА НАНУ. Ф. 60 ІІМК - Спр. 471. Зв'язок з науковими установами СРСР. - 14 арк.

НА IA НАНУ. Ф. 60 ІІМК - Спр. 623, Протоколи наукових зборів ІІМК - 15 протоколів з 2-х прим. - 68 арк.

НА IA НАНУ. Ф. 60 ІІМК - Спр. 614. Ячменьов М. І. , Теличко В. П. Інститут історії матеріальної культури АН УРСР у 1936 р. - 43 арк.

НА IA НАНУ. Ф. 60 ІІМК - Спр. 630. Археологія за 20 років. - 15 арк.

HA IA НАНУ. Ф. 60 IІМК - Спр. 638. Козубовський Ф. А. XVII з’їзд ВКП(б) та завдання історії матеріальної культури (Вступна стаття до 2 кн. “Наукових записок ІІМК” в двох варіантах). - 15 арк.

НА ІА НАНУ. Ф. 60 ІІМК - Спр. 637. Історія матеріальної культури за 20 років Великої Жовтневої Соціалістичної Революції. - 25 арк.

Научный архив Института истории материальной культуры Российской академии наук. Ф. 35. Оп. 5. Ед. хр. Личное дело Л. М. Славина (1929-1938).

Пастернак Я. I. (1961). Археологія України: Первісна, давня та середня історія України за археологічними джерелами. - Торонто: Наукове товариство ім. Шевченка. - 783 с.

Полонська-Василенко Н. Д. (1993). Українська Академія Наук (Нарис історії). - Київ. - 414 с.

Полонська-Василенко Н. (1962). Історична наука в Україні за совєтської доби та доля істориків // Записки Наукового товариства ім. Т. Г. Шевченка: Збірник на пошану українських учених знищених большевицькою Москвою. - Т. 173. - С. 7-111. 
Славин Л. М. (1940). Научная конфернция археологов, изучающих историю Украины в скифосарматский период // Вестник древней истории. - № 1. - С. 200-207.

Славін Л. М. (1943). Основні підсумки вивчення Ольвії за радянський період // Наукові записки Інституту історії і археології АН УРСР. - Вип. 1. - С. 67-99.

Славін Л. М. (1947). 25 років археологічних досліджень Академії наук УРСР // Археологія. Вип. 1. - С. 65-84.

Смолій В. А., Удод О. А., ЯсьО.В. (2016). Інститут історії України НАН України: віхи інституціональної та інтелектуальної історії // Український історичний журнал. - Вип. 5. - С. 4-36.

Станіцина Г. О. (2007). Особистість Л. М. Славіна за матеріалами Наукового архіву IA НАН України // Археологія. - № 1. - С. 21-30.

Шовкопляс I. Г. (1969). Розвиток радянської археології на Україні (1917-1966). - Київ. - 340 с.

Trigger Bruce G. A. (1989). History of Archaeological Thought. Cambridge University Press. 500 p.

\section{REFERENCES}

50 let Institutu arheologi AN USSR. (1984). Kiev, 138 (in Russian).

Arkhiv Prezydii Natsionalnoi akademii nauk Ukrainy. F. R-251 Viddil naukovykh kadriv i aspirantury. Osobova sprava L. M. Slavina. Sprava bez vykhidnykh danykh (in Ukrainian).

Gening, V. F. (1982). Ocherki po istorii sovetskoj arheologii (u istokov formirovanija marksists'kih teoreticheskih osnov sovetskoj arheologi. 20-e - pervaja polovina 30- $h$ godov). Kiev, 228 pp. (in Russian).

Tolochko, P. P. (Ed.). (2015). Instytut arkheolohii Natsionalnoi akademii nauk Ukrainy. 1918-2014. Kyiv, 668 pp. (in Ukrainian).

Smolii, V. A. (Ed.). (2011). Instytut istorii Ukrainy Natsionalnoi akademii nauk Ukrainy. Dokumenty $i$ materialy. 1936-1991: Knyha 1. 1936-1947. Kyiv, 630 pp. (in Ukrainian).

Smolii, V. (Ed.). (2016). Istoryk i Vlada. Kyiv, 543 pp. (in Ukrainian).

Kolesnykova, V. A., Mykhailova, N. R., Chernovol, I. V., \& Naumenko, N. V. (2008) Istoriia Naukovoi biblioteky Instytutu arkheolohii NAN Ukrainy. Arkheolohiia, 4, 104-111 (in Ukrainian).

Korpusova, V. M. (2007). Lazar Moiseiovych Slavin - Dyrektor Instytutu arkheolohii Akademii Nauk Ukrainy. Arkheolohiia, 1, 31-39 (in Ukrainian).

Korpusova, V. N. (1996). L. M. Slavin - direktor Instituta arheologii Ukrainy. Mir Ol'vii. K 90-letiju prof. L. M. Slavina, 24-31 (in Russian).

Kurinnyi, P. P. (1994). Istoriia arkheolohichnoho znannia pro Ukrainu. Poltava, 140 pp. (in Ukrainian).

Mezentseva, H. H. (1997). Doslidnyky arkheolohii Ukrainy. Entsyklopedychnyi slovnyk. Chernihiv, 206 pp. (in Ukrainian).

Miller, M. A. (1954). Arheologija v SSSR. Mjunhen, 160 pp. (in Russian).

Miller, M. O. (1962). Dolia ukrainskykh arkheolohiv pid sovietamy. Zapysky Naukovoho tovarystva im. T. H. Shevchenka: Zbirnyk na poshanu ukrainskykh uchenykh znyshchenykh bolshevytskoiu Moskvoiu, 173, 112-126 (in Ukrainian).

Naukovyi arkhiv Instytutu arkheolohii Natsionalnoi akademii nauk Ukrainy. F. 59 VUAK. Spr. 686 a. Khronika arkheolohii ta mystetstva. Ch. 1. Kyiv. (in Ukrainian).

Naukovyi arkhiv Instytutu arkheolohii Natsionalnoi akademii nauk Ukrainy. F. 59 VUAK. Spr. 462. Spysky chleniv VUAK, 69 ark. (in Ukrainian).

Naukovyi arkhiv Instytutu arkheolohii Natsionalnoi akademii nauk Ukrainy. F. 60 IIMK. Spr. 471. Zv'iazok z naukovymy ustanovamy SRSR, 14 ark. (in Ukrainian).

Naukovyi arkhiv Instytutu arkheolohii Natsionalnoi akademii nauk Ukrainy. F. 60 IIMK. Spr. 623, Protokoly naukovykh zboriv IIMK - 15 protokoliv z 2-kh prym. - 68 ark. (in Ukrainian).

Naukovyi arkhiv Instytutu arkheolohii Natsionalnoi akademii nauk Ukrainy. F. 60 IIMK. Spr. 614. Yachmenov M. I., Telychko V. P. Instytut istorii materialnoi kultury AN URSR u 1936 r., 43 ark. (in Ukrainian).

Naukovyi arkhiv Instytutu arkheolohii Natsionalnoi akademii nauk Ukrainy. F. 60 IIMK. Spr. 630. Arkheolohiia za 20 rokiv, 15 ark. (in Ukrainian). 
Naukovyi arkhiv Instytutu arkheolohii Natsionalnoi akademii nauk Ukrainy. F. 60 IIMK. Spr. 638. Kozubovskyi F. A. XVII z'izd VKP(b) ta zavdannia istorii materialnoi kultury (Vstupna stattia do $2 \mathrm{kn}$. "Naukovykh zapysok IIMK" v dvokh variantakh), 15 ark. (in Ukrainian).

Naukovyi arkhiv Instytutu arkheolohii Natsionalnoi akademii nauk Ukrainy. F. 60 IIMK. Spr. 637. Istoriia materialnoi kultury za 20 rokiv Velykoi Zhovtnevoi Sotsialistychnoi Revoliutsii, 25 ark. (in Ukrainian).

Nauchnyj arhiv Instituta istorii material'noj kul'tury Rossijskoj akademii nauk. F. 35. Op. 5. Ed. hr. Lichnoe delo L. M. Slavina (1929-1938) (in Russian).

Pasternak, Ya. I. (1961). Arkheolohiia Ukrainy: Pervisna, davnia ta serednia istoriia Ukrainy za arkheolohichnymy dzherelamy. Toronto: Naukove tovarystvo im. Shevchenka, 783 pp. (in Ukrainian).

Polonska-Vasylenko, N. D. (1993). Ukrainska Akademiia Nauk (Narys istorii). Kyiv, 414 pp. (in Ukrainian).

Polonska-Vasylenko, N. (1962). Istorychna nauka v Ukraini za sovietskoi doby ta dolia istorykiv. Zapysky Naukovoho tovarystva im. T. H. Shevchenka: Zbirnyk na poshanu ukrainskykh uchenykh znyshchenykh bolshevytskoiu Moskvoiu, 173, 7-111 (in Ukrainian).

Slavin, L. M. (1940). Nauchnaja konferncija arheologov, izuchajushhih istoriju Ukrainy v skifosarmatskij period. Vestnik drevnej istorii, 1, 200-207 (in Russian).

Slavin, L. M. (1943). Osnovni pidsumky vyvchennia Olvii za radianskyi period. Naukovi zapysky Instytutu istorii i arkheolohii Akademii nauk USSR, 1, 67-99 (in Ukrainian).

Slavin, L. M. (1947). 25 rokiv arkheolohichnykh doslidzhen Akademii nauk URSR. Arkheolohiia, 1, 6584 (in Ukrainian).

Smolii, V. A., Udod, O. A., \& Yas, O. V. (2016). Instytut istorii Ukrainy NAN Ukrainy: vikhy instytutsionalnoi ta intelektualnoi istorii. Ukrainian historical journal, 5, 4-36 (in Ukrainian).

Stanitsyna, H. O. (2007). Osobystist L. M. Slavina za materialamy Naukovoho arkhivu IA NAN Ukrainy. Arkheolohiia, 1, 21-30 (in Ukrainian).

Shovkoplias, I. H. (1969). Rozvytok radianskoi arkheolohii na Ukraini (1917-1966). Kyiv, 340 pp. (in Ukrainian).

Trigger Bruce, G. A. (1989). History of Archaeological Thought. Cambridge University Press, 500 pp.

Стаття: надійшла до редакції 6.11.2018

прийнята до друку 6.12.2018

\section{ЛАЗАР СЛАВІН У КОНТЕКСТІ РОЗВИТКУ \\ ІНСТИТУЦІЙНОЇ АРХЕОЛОГІЇ В УРСР (1938-1941)}

\section{Дар'я ЧЕРКАСЬКА}

Центр археологї, відділення гуманітарних наук та мистецтва Стаффордширського університету, м. Сток он Трент, Коледж роуд, буд. Флаксман, км. L214, e-mail: dcherkasskaya@gmail.com

Розвиток археологічної науки в Україні у радянський час тісно пов'язаний з діяльністю Лазаря Славіна (1906-1971) - члена-кореспондента Академії наук УРСР, антикознавця, кандидата історичних наук, професора, засновника та керівника кафедри археології та музеєзнавства Київського державного університету імені Т.Г. Шевченка. Постать Л. Славіна, який був серед організаторів і керівників української радянської археології починаючи з 1930-х рр., варта окремого дослідження. Діяльність Л. Славіна припала на складний для науки період, коли дослідження підпорядковувалися не принципам об'єктивізму та науковості, а концепціям та догмам, що визначалися владою, як єдино вірні. Тому професійна діяльність науковця у цьому дослідженні розглядається не тільки з точки зору розвитку наукової думки, але і з точки зору політико-ідеологічних впливів, як безпосередньо на Л. Славіна, так і на гуманітарні науки загалом.

Ключові слова: Лазар Славін, радянська археологія, історія археології, інституційна археологія, Інститут археології НАН України. 